\title{
Beyond Basic Education: Exploring Opportunities for Higher Learning in Kenyan Refugee Camps
}

\author{
Laura-Ashley Wright and Robyn Plasterer
}

\begin{abstract}
This paper seeks to elucidate the socio-cultural and economic benefits of higher education in refugee contexts. NGO and UNHCR initiatives in Dadaab and Kakuma camps are used as a reference point for discussing the challenges, best practices, and potential of higher and adult learning in contexts of protracted exile. This small-scale, qualitative study seeks to understand what opportunities for higher education exist for those living in Kenyan refugee camps, and do existing opportunities yield "social benefits" beyond those accrued by the refugees themselves? Drawing upon interviews with practitioners, observation in schools and learning centres, and data from refugee-service providers, our findings are primarily descriptive in nature and explore the myriad ways in which opportunities for higher learning can strengthen refugee communities in countries of asylum. We contend that although Kenya's encampment policies limit the potential economic and social benefits of refugee education on a national level, opportunities for refugees to pursue higher education are still immensely valuable in that they bolster refugee service provision in the camps and provide refugees with the skills and knowledge needed to increase the effectiveness of durable solutions at both an individual and societal level, be they repatriation, local integration, or third-country resettlement.
\end{abstract}

\section{Résumé}

Cet article cherche à déterminer les avantages socioculturels et économiques d'une éducation supérieure pour les réfugiés. Des initiatives d'ONG et du Haut Commissariat des Nations Unies pour les réfugiés (UNHCR) dans les camps de Dadaab et de Kakuma servent de points de référence pour une discussion des défis, des pratiques exemplaires et des possibilités d'une éducation supérieure et d'un enseignement aux adultes dans des contextes d'exil prolongé. Cette étude qualitative à petite échelle cherche à déterminer les possibilités d'offrir une éducation supérieure aux habitants des camps de réfugiés au Kenya et à établir si les occasions existantes donnent lieu à des "avantages sociaux " autres que ceux qui sont acquis par les réfugiés eux-mêmes. Fondées sur des entrevues avec des praticiens, des observations dans les écoles et les centres d'apprentissage ainsi que des données obtenues de fournisseurs de services aux réfugiés, nos constatations sont essentiellement descriptives et explorent les multiples façons dont les possibilités d'une éducation supérieure peuvent renforcer les communautés de réfugiés dans les pays d'asile. Nous soutenons qu'en dépit des politiques du Kenya sur le regroupement des réfugiés qui limitent les avantages économiques et sociaux potentiels de l'éducation des réfugiés à l'échelle nationale, les possibilités qu'ont les réfugiés de poursuivre des études supérieures demeurent précieuses en ce qu'elles renforcent la prestation de services dans les camps et fournissent aux réfugiés les compétences et les connaissances qui sont nécessaires à l'établissement de solutions durables plus efficaces, tant au niveau individuel que sociétal, qu'il s'agisse de rapatriement, d'intégration locale ou de réinstallation dans un tiers pays.

\section{Introduction}

Debates concerning higher education in the Global South, and Sub-Saharan Africa in particular, have been at the forefront of international education policy and scholarship since the 1970s. ${ }^{1}$ The key question at hand has been whether or not higher education provides valuable social benefits at large, or simply posits personal rewards to those who have better access. In essence: do the private returns outweigh the relative social benefits of higher education in a development context? Until recently, this dialogue has focused on 
the outcomes of higher education for individuals within the nation-state system, but has rarely been extended to contexts of protracted exile. This paper seeks to address this gap by elucidating the value of higher education in protracted refugee situations with specific reference to Kenya.

We suggest that opportunities for higher and adult education, in contexts of displacement, can yield important "social benefits" beyond the personal gain accrued by individual refugees themselves. Such benefits include, but are not limited to: strengthening the quantity and quality of the teaching force within the camps, bolstering parental support for and engagement with their children's education (particularly girls' education), and promoting primary and secondary school attendance by ensuring opportunities, be they limited, to pursue higher learning. However, before delving into the case of higher learning in Kenyan camps, we will first contextualize our findings with a brief overview of the key debates concerning higher education in Africa.

\section{Higher Education in Africa}

From the 1970s to the late 1990s, the World Bank viewed public spending on higher education as a misdirection of resources, stating that individuals reaped far greater benefit from higher education on a personal rather than collective level. Institutions for higher education were seen as "enclaves of privilege," and the international community supported this position by channelling almost all funding to basic education. ${ }^{2}$ The prioritization of "Education for All," limited to basic education, resulted in a severe deterioration of higher education in Africa. ${ }^{3}$ This focus was supported by four key arguments. First, the expansion of the education regime to include higher education institutions would reduce the quality of education at all levels. ${ }^{4}$ Second, it would foster a disjuncture between supply and demand in regions where the labour market is unable to absorb graduates. ${ }^{5}$ Third, higher education often excludes disadvantaged and marginalized groups, ${ }^{6}$ as developing countries lack the financial markets needed to provide student loans; corruption among university placements and scholarships is also widely cited. ${ }^{7}$ This leads to the fourth line of argument: a very small percentage of the population can access higher education, yet this group receives a disproportionately large percentage of educational budgets. ${ }^{8}$

At present, one quarter of international aid to the education sector in Sub-Saharan Africa is targeted to higher education. ${ }^{9}$ This reflects a change since the 1990s to a more positive outlook, with higher education being favourably repositioned in development thinking. ${ }^{10}$ Part of the change can be attributed to the 1999 World Bank report, Knowledge for Development, which showed that private rates of return for higher education were similar to those of secondary education, recommending the promotion of distance learning in development contexts. ${ }^{11}$ Moreover, the 2002 World Bank Report, Constructing Knowledge Societies: New Challenges for Tertiary Education, signified a shift in the Bank's position and emphasized the potential of Information and Communication Technologies (ICTs) and distance learning, the role of higher education in development and economic growth, and the importance of a holistic education system as a "global public good."12 Unfortunately, despite these developments, 2008 enrolment rates for higher education in Africa stood at 6 per cent, compared to the global average of 26 per cent and 70 per cent in North America and Western Europe. ${ }^{13}$

\section{Higher Education in a Refugee Context}

Investment in higher education may be even more controversial apropos refugee populations (see also DrydenPeterson, this issue). With severe restrictions on movement, commerce, and citizenship rights for "warehoused"14 populations in Kakuma and Dadaab, it is difficult to see how providing higher education within the camps would forward national development along the lines specified in the literature. For instance, higher education is unlikely to benefit Kenya's national economy or social fabric, unless the Kenyan government were to revise its policies of encampment and facilitate local integration. Moreover, given the long-term effort and investment needed to provide opportunities for higher education in remote and under-resourced locations (such as refugee camps), and the fact that primary and secondary education also remain in desperate need of additional assistance and funding, it is reasonable to question whether the international community should prioritize higher/adult education and training at all.

In this paper we take the position that higher education in refugee situations is critical not only to achieving socioeconomic development, but also to bolstering durable solutions for both individuals and society. As an investment, it is therefore as essential in refugee contexts as in development contexts.

First, higher education and training can provide refugees with the skills and knowledge needed to increase the effectiveness of durable solutions, be they repatriation, local integration, or third-country resettlement. When speaking to repatriation, there is no shortage of research indicating the critical role for higher education in nation building and peace making, particularly in countries recovering from war. ${ }^{15}$ The Task Force on Higher Education and Society states that higher education "is essential to national social and economic development." 16 The benefits of higher education, including increased tax revenue, better national health, reduced population growth, stronger government, 
and improved technology, ${ }^{17}$ apply not only to a context of repatriation but also to local integration. Moreover, in terms of third-country resettlement, a recent report by the NGO Network of Integration Focal Points indicates that efforts in education, vocational training, and language learning assist refugees to play an active role in their own integration, enabling them and their children to "be more successful and more active participants in society." 18

With the average time spent as a refugee doubling from nine to seventeen years over the last decade, ${ }^{19}$ Zeus notes that "we cannot afford to have human potential linger around until a durable solution is found ... we need to look at the immediate and long-term development needs of refugees in protracted contexts." 20 To do so, she argues that the international community should provide refugees with the essential capacity building opportunities during displacement, to cultivate skills for future integration and community/nation building efforts. The benefits of such programming have been widely documented and may include: bolstering parental and community support for primary and secondary education initiatives, particularly for gender equity programs; improving the quality and capacity of the primary and secondary education system by increasing the number of qualified teachers; inspiring youth to attend class and successfully complete high school, thus helping to limit social deviancy and "recruitment into armed combat, forced labour, drug trafficking and prostitution." 21 Further, higher education can enable refugees to "participate in planning and policy making regarding their own situation, empower[ing] them to be no longer a "burden," but agents of their own development." 22

The challenge of higher education embodies the paradox of "relief versus development." The relief model stems from the premise that "the crisis will have a beginning, a middle, and an end," where donors seek to assess needs quickly and devise a response strategy as efficiently as possible. ${ }^{23}$ The relief focus often excludes education, as prioritized urgent needs are intended to be short term, such as the distribution and provisioning of material aid, constructing short-term shelters, and providing support for post-traumatic stress. ${ }^{24}$ As such, the "top-down management of activities" 25 related to care and maintenance is often critiqued for creating refugee dependency syndrome, for disempowering, "pathologizing, medicalizing, and labeling" refugees, and for creating tensions between those who receive aid and those who don't. ${ }^{26}$ Indeed, many scholars have noted how "care and maintenance" programs for long-term refugees not only can create donor fatigue, but also can confine refugees' personal and community development in particular ways by creating dependency on aid. ${ }^{27}$
Conversely, the development model, articulated by Mimica and Stubbs, suggests that "refugee emergencies can, also, be seen as opportunities for development." ${ }^{28}$ As refugee crises are rarely short term, "it is imperative to begin long-term planning from day one." 29 The approach "implies a high degree of both participant and self-sufficiency by the beneficiary population," 30 and research "suggests that those refugees who achieve higher levels of adaptation are those most prepared to return to their homes when that becomes possible. The development model is about giving people choices rather than inducing passivity and a feeling of helplessness." 31 However, development planning is more complex, taking into account short- and long-term planning for programming in education, skills development, income generation, and public health awareness. ${ }^{32}$ Kaiser notes how the "inherently political nature of refugee presence" makes the implementation of a developmental response incredibly difficult. ${ }^{33}$ Crisp elaborates on these political divides within institutions that provide relief and development, such as tensions between United Nations High Commissioner for Refugees (UNHCR) and United Nations Development Programme (UNDP), the US State Department's Bureau for Refugee Programs, and USAID. ${ }^{34}$ To add to this complication, many host states, such as Kenya, want to ensure that any efforts within a development framework are not interpreted as being in favour of local integration. Given the international community's preference for repatriation, ${ }^{35}$ development-focused efforts, such as in education, have been limited.

We use a case study of the Kenyan refugee camps to illuminate our argument about the critical nature of higher education for refugees. We begin by providing an overview of higher/adult education and training programs in Kakuma and Dadaab (including adult literacy, Technical and Vocational Education Training (TVET), Teacher Training Programs (TTP), distance/higher education, and scholarship opportunities). We then explore the challenges facing higher education in refugee contexts broadly, and some of the NGO- and community-driven initiatives that are working to overcome these barriers in Kenya. Though descriptive in nature, and limited to the perspective of service providers, our findings support the premise that opportunities for higher learning can yield important social benefits to communities in protracted exile in a number of ways.

\section{Education in Protracted Refugee Situations: The Case of Kenya}

Kenya is noted to be in the "unenviable geographical position" of sharing borders with five countries, of which four "have generated sufficient internal conflict" to create masses of refugees and asylum seekers in Kenya. ${ }^{36}$ As 
the second-largest refugee-hosting country in Africa after Tanzania, ${ }^{37}$ Kenya has followed a strict policy of encampment since 1992. This policy of "refugee warehousing and containment" 38 has resulted in the present-day remote refugee camps of Kakuma and Dadaab, near the borders of Sudan and Somalia respectively. The locations of these camps were selected partly for their geographical proximity to origin country borders, but also for their remoteness and lack of agricultural value and economic significance. ${ }^{39}$ The remoteness and confinement characterizing these camps not only adversely affects educational attainment at the primary level but, according to data obtained during this research, implicates the availability and quality of secondary, higher, and adult education as well.

\section{Education in Dadaab}

The largest refugee camp in the world, Dadaab is located in northeastern Kenya's Garissa District, approximately one hundred kilometres from the Kenya-Somalia border and consists of three sub-camps: Ifo, Dagahaley, and Hagadera. Established in 1991 with a capacity to host 90,000 refugees, the camp has grown to host approximately 313,309 refugees (as of March 2011) of which 94 per cent originate from Somalia. ${ }^{40}$ Similar to Kakuma, Kenya's only other refugee camp, Dadaab is located in a semi-arid climate and experiences severe weather (extreme heat in the dry season and widespread flooding in the wet season), as well as frequent hostility from the local population. ${ }^{41}$ These living conditions create an extremely precarious situation for refugees with 43 per cent of the population lacking adequate dwellings, 82 per cent lacking household latrines, and almost all being affected by water shortages. ${ }^{42}$

Educational provision is a further impediment; 118,915 youth are school-going age (five to seventeen years of age), ${ }^{43}$ yet roughly half are not in school. ${ }^{44} \mathrm{UNHCR}$ states that providing every child in Dadaab with access to formal education would require the construction of forty-six additional schools. ${ }^{45}$ As of August 2009, the teacher-student ratio was $1: 68$, and 92 per cent of these teachers were untrained. ${ }^{46}$ Within the three camps, there are eighteen primary schools that cater to 37,125 learners (39 per cent girls) as of $2009 ;{ }^{47}$ three main secondary schools, initiated by NGOs, with 1,644 learners (26 per cent girls); and three community secondary schools, initiated by the refugee community, with 1,048 learners (18 per cent girls), as of $2010 .{ }^{48}$ The schools are supported by UNHCR, Windle Trust Kenya, and Care International. Despite a growing number of refugee youth in the camp, funding and resources remain relatively static. However, the UNHCR Dadaab office reminds us that "the youth is eager for livelihood opportunities and training courses." 49

\section{Education in Kakuma}

Situated in the Turkana District of northwestern Kenya, Kakuma hosted a population of 80,741 as of 24 July 2011; 7,241 refugees are new arrivals in 2011, with a current trend of approximately 270 new arrivals per week. ${ }^{50}$ This population more than doubled in size from 2009, mainly a result of Sudanese repatriation and a relocation of Somali refugees from an overcrowded Dadaab. In the past, the majority of residents were Sudanese, but with recent demographic shifts the population breakdown in July 2011 was: 53.6 per cent Somali, 31.3 per cent Sudanese, 6.8 per cent Ethiopian, 5.2 per cent Congolese (Democratic Republic), 1.8 per cent Burundian, and a remaining 1.3 per cent from Uganda, Congo, Rwanda, Eritrea, and Tanzania. ${ }^{51}$ Since the start of the Sudanese repatriation, Kakuma has seen severe cutbacks to its educational programming; however, the school system continues to support 15,399 students (6,452 girls) by operating six preschools, ten primary schools, and one secondary school. ${ }^{52}$ In August 2009, of the 220 teachers in the camp, 81 per cent were untrained. As in Dadaab, girls' educational attainment steadily decreases with age, such that by secondary school only 67 of the 394 students were girls (2009 data). ${ }^{53}$ However, there is hope for gender equity; in both camps (Kakuma and Dadaab), 240 refugee girls in their final year of primary school benefited from remedial education classes (2009 data). ${ }^{54}$

\section{Methodology}

Fieldwork for this small-scale qualitative study was carried out over three weeks in Kenya, with one week in Kakuma, Dadaab, and Nairobi respectively. During this time we conducted in-depth, semi-structured interviews with NGO and UNHCR representatives at all sites. Triangulation ${ }^{55}$ was used through the collection of "rich data" in the form of verbatim transcripts and in situ observation from two different camp settings, along with primary and secondary documentary research. ${ }^{56}$ While our data incorporated all levels of education, we chose to focus our attention and analysis on higher learning for the reasons outlined above. Many refugees shared their frustrations of feeling idle and forgotten by the international community, as well as their desires to continue their education and skills development later in life. They explained that conflict disrupted their education, and that the current camp education system did not provide adequate transition opportunities for adults or youth with some schooling in their countries of origin and who wished to re-enter formal schooling under the Kenyan system offered in the camps; by the time they would manage to finish secondary school, they would be too old for many of the current scholarship schemes. Additionally, we were frequently asked by refugees (many of whom mistook 
us for donors) as to why most scholarship opportunities had age limitations and whether there were opportunities for individuals over twenty-five years of age. It is in response to those conversations, as well as the aforementioned gap in the literature, that we have sought to consolidate information on existing opportunities for higher/adult refugee education in Kenya.

While these conversations are an underlying motivation for this paper, we ultimately chose to refrain from interviewing refugees in the camps due to numerous moral and ethical dilemmas, ${ }^{57}$ including the difficulties of attaining informed and voluntary consent given our time constraints and the power imbalances between ourselves and potential participants; the chance that the "fly in, fly out" nature of the research may have left participants feeling "exploited"; and the expectations that were raised by presumptions that we were rich dibadaha (outsiders) from the "West" with access to resources and resettlement opportunities. ${ }^{58}$ As such, we only interviewed service providers working directly with educational and vocational programming. In so doing, certain voices have been silenced and we are thus unable to "identify similarities and differences in perception between implementing agencies and the refugees" in Dadaab. ${ }^{59}$ The dearth of refugee voices within this paper is an important limitation of the research and, as such, the findings herein should be read with this in mind.

However, while refugee youth were not directly interviewed for this research, ${ }^{60}$ we did engage in reciprocal learning with refugee youth in the camps by conducting a series of pre-departure orientations for World University Service of Canada's refugee students being resettled to Canada in collaboration with our NGO host. As part of their pre-departure training, run by WUSC and Windle Trust, the students complete an extensive piece of primary research on topics of importance in the camps such as: education; health; crime; food and nutrition; sanitation; and environmental sustainability. We have used selected data from these reports for which they gave consent for use in our research. Prior to conducting their research, all students received training on research methods and ethics.

Our NGO host aided our research by facilitating the logistics and security of visits to all of the sub-camps within Kakuma and Dadaab, and assisting with site visits to primary, secondary, and adult schools (both community-led and mainstream); ICT learning centres; libraries; vocational training centres; refugee reception/registration centres; and community sites such as churches and restaurants. This collaboration enabled us to attend classes of the girl child education and adult literacy programs, meet with community leaders and refugee teachers, and attend a graduation ceremony for refugee youth; however, all of these visits were dependent on the transportation and often, language interpretation of our host.

While hosts (such as NGOs) can improve reliability and validity of data, it is important to note that there are also ethical and methodological concerns, such as reactivity, where the "active presence" of researchers and guides produces biased responses and resistance to reveal the "real truth."61 Bowman notes that certain organizations working with refugees may wish to prevent access to these "real truths," instead being "keen to display an impression of unity to the outsider, downplaying the process of internal discord, conflict, or factionalism." 62 Jacobsen and Landau recommend prolonging fieldwork to reduce bias and reveal inconsistencies; ${ }^{63}$ however, this was not possible within the timeframe of our fieldwork. As we were also unable to obtain the visitor permits required to extend our stay in the camps, followup email interviews and communication were used as an attempt to verify the data.

Although it can be extremely difficult to collect a range of data due to the challenges previously mentioned, networking with NGOs proved extremely beneficial, as we were able to find a substantial amount of documentary evidence and had access to many key informants. To enhance the quality of data, participants with diverse experiences, opinions, and insights were selected based on purposive sampling, including at least one NGO worker from each organization involved in education in the camps plus UNHCR. In total, fifteen semi-structured interviews were carried out with representatives from NGOs working in the education sector (in the camps and in Nairobi) and the UNHCR (at the field offices in the camps).

Despite the relatively small size of our sample, interviews with the above participants elicited a range of perspectives in an attempt to identify the social, cultural, economic, and political factors impacting the provision of education in the refugee camps. The interviewees included representatives of UNHCR, Care International, Windle Trust Kenya, the Norwegian Refugee Council, the Jesuit Refugee Service, the Lutheran World Federation, and Don Bosco. All participants were informed of the consent procedures, assured that all data would be anonymized, and asked for permission to record the interview. They had a strong grasp of English and were given the opportunity to review interview transcripts and notes to ensure accuracy. ${ }^{64}$ We feel it is important to note that all the participants currently work for their respective organizations, which may have implicated their ability to share certain information and may create bias in our data. The majority of interviews took place at the respective offices of the participants, allowing for observations and field notes to be collected at each site, including schools, the university campus, ministry buildings, and ICT 
centres. The questions posed were general, asking for perceived strengths and challenges to providing education and allowing for each participant to answer within their own experience. The following sections outline our key findings from these meetings with respect to adult literacy and training, teacher training programs, higher education opportunities, and community learning initiatives.

\section{Challenges Facing Higher Education for Refugees in Kenya}

There are several key factors reported as challenges to the education system in Kenyan refugee camps, including cultural/traditional practices that do not favour girl's education, congestion in schools, dilapidated and under-resourced facilities, and a paucity of trained teachers. However, according to all of our research participants, at the forefront is the challenge of providing sufficient funding for educational opportunities. Existing (and limited) funding, usually from donor agencies, is often targeted towards primary and secondary education provision, with an emphasis on Girl Child Education (GCE) (Interviewees 1, 2, 3, 5, 7, 8, 10, 11, 13 and 15). As such, the dearth of resources for higher education remains acute. As one NGO worker in Kakuma articulated:

Support for secondary school and post-secondary school is still a big problem [...] There are very few sponsors for such students.Interviewee 3

When asked about the biggest obstacle facing education in the camps, another practitioner stated:

Over time I've come to realize that education is not a priority in a refugee camp. Donors want to provide water, food and healththose are the priorities. Education is the second. But to me, education should be the top priority because if you have an educated group among the refugees they could also facilitate to deal with those issues. - Interviewee 8

This reluctance to fund education can be attributed to a donor emphasis on temporary relief rather than longterm development. As one ESL/ICT teacher in Kakuma expressed:

The refugee situation is seen as a temporary situation, so we don't want them to have very permanent structures, permanent programs that will draw refugees to the camp instead of encouraging them to go back home. That's how we see it, but the fact remains that some refugees have been here since 1992! -Interviewee 15
These limited resources impact on all areas of the provision of higher education for refugees in Kenya.

\section{Adult Literacy and Training}

There are several educational programs catering to adult populations in both camps. Among these, English as a Second Language (ESL) Training and TVET are the most prominent. Windle Trust Kenya (WTK) provides ESL to refugees in both camps in order to meet the identified needs of five key target groups: vulnerable women for empowerment, survival, and protection; community leaders to communicate with relevant authorities; incentive teachers for professional development and language-upgrading; out-ofschool youth wishing to enter formal schooling or obtain employment as incentive workers; ${ }^{65}$ and the host community, who are "equally disadvantaged when it comes to language literacy and who resent the opportunities provided to refugees but not to them" (Interviewee 3). These ESL programs are of value not only to the individual participants, but also to the wider community; for example, one NGO worker noted how literacy programs can even assist with conflict resolution in a multicultural camp setting such as Kakuma:

You find that there are more than ten nationalities in the camps, in addition to the different clans from the same country that may not be speaking the same language. English helps leaders to come together and talk to understand each other, to appreciate one another, and therefore it becomes a tool of reconciliation-a tool of peace. - Interviewee 8

Additionally, an ESL program coordinator stated how:

English language literacy programs, apart from providing access to services, provide skills in mediation, protection and empowerment, skills that can help refugees to seek jobs within organizations; not just the skills to ask for jobs, but to be able to do the jobs, being confident to speak and to have selfesteem in themselves. A person who is incapacitated because of communication cannot have self-confidence-a sense of ownership comes from this. - Interviewee 3

WTK also runs several ESL classes in collaboration with Don Bosco as part of additional non-formal adult education opportunities, such as within gender-based awareness or life choices outreach programs, business management skills, computer or secretarial certificate courses, or micro-finance credit programs coordinated by UNHCR. These courses are short in duration, lasting approximately three to six months, and change in content to reflect the needs and desires of the refugee population (Interviewee 3 ). 
As the main provider of technical and vocational training in Kakuma, Don Bosco is registered with the Government of Kenya to offer three grades of TVET; each is one year in duration. Upon completion of these courses, refugees receive three certificates: one from the Government of Kenya, one from UNHCR, and one from Don Bosco. Course options change frequently to meet refugee preferences, but often include skills such as carpentry, welding, mechanics, masonry, plumbing, electrical wiring, tailoring, dressmaking, and agriculture. TVET is free and open to adults from ages sixteen to fifty, with the only entrance requirement being completion of primary school. While Don Bosco's mandate includes adults as a target group (Interviewee 4), practitioners continually reported an overall shortage of educational opportunities in the camps (Interviewees 1, 3, $4,7,8,13)$. Challenges noted include: language barriers for those with different levels of English and for French speakers; the need to constantly adapt programs to ensure student retention, as many refugees state a desire to begin a program, but then drop out from a loss motivation to work; the complication of simultaneously meeting the needs of refugees and donors, as UNHCR targets include vulnerable groups such as women, school dropouts and the physically handicapped; and the costs of providing a meal to refugees and ensuring the courses remain free (Interviewees 1, 3, 4, $5,7,10,13,15)$.

Unfortunately, we were unable to collect any data on ongoing TVET initiatives for adults at the time of our research, as many programs had recently experienced severe cuts or suspension, and those remaining were primarily geared towards youth. ${ }^{66}$ These funding challenges were reported by all interviewees as a major barrier to providing education, especially TVET. That said, Care International and Samasource, a US-based NGO, fund ICT learning centres in Dadaab and coordinate with other NGOs to provide Income-Generating Activities (IGA) and adult training in technology.

Many interviewees emphasized the importance of ESL and TVET programs as effective education options for refugees, stating how the programs provide graduates with practical and tangible skills needed to make important contributions to NGOs as incentive workers, generating income in an otherwise non-existent job market ${ }^{67}$ (Interviewees 1 , $2,3,4,8,11,14) .{ }^{68}$ Beyond income-generating opportunities, adult learning can also strengthen the value parents place on education, thus enhancing their support for primary and secondary education initiatives, particularly with respect to Girl-Child Education (GCE).

Numerous academics and practitioners support the premise that "parent/caregiver expectations, positive or negative, toward schools and the child's capacity, have a great impact on the child's enrolment, persistence and attainment," 69 with UNICEF reporting that:

Children whose parents have primary school education or less were more than three times as likely to have low test scores or grade repetition than children whose parents have at least some secondary schooling [...] Parents with little formal education may also be less familiar with the language used in school, limiting their ability to support learning and participate in school-related activities. $^{70}$

This position was corroborated by many of our interviewees, who believed that in many cases children's low enrolment and attainment could, in part, be contributed to a lack of parental engagement that stemmed from a dearth of adult education and literacy programs in the camps (Interviewees $3,14)$. However, it was also noted that the few existing opportunities for adults do assist in strengthening community perceptions of education by generating parental awareness of the socio-economic benefits of proving education for one's children (Interviewees 3, 8, 9, 10, 14). ${ }^{71}$

Throughout the interviews, two key issues were continually identified by participants as implicating community and parental support of youth education: culture and gender. Family responsibilities, domestic duties, and cultural norms were cited as preventing women and girls from participating in NGO programs, including formal schooling (Interviewees 2, 3, 5, 6, 7, 8, 13, 15). Moreover, interviewees spoke of how girls are frequently victims of gender-based violence, including: early, arranged, or forced marriages; shame and exclusion from poorly performed female genital mutilation practices; and mothers practising commercial sex or brewing alcohol in the home, exposing girls to rape, abuse, STIs, and HIV and AIDS (Interviewees $2,6,12,14)$. Several participants articulated that while culturally constructed gender roles have been a long-standing impediment to girls' access to education in Kenyan camps, recent efforts by NGOs have improved female attendance; Interviewee 14 elaborates:

Girls are just considered as means of income. For [communities], [girls] are not entitled to go to school-they are entitled to be a housewife. Because when they reach a certain level, they will be forced to drop out and then get married, then give birth, then become mothers. But now, this is not the case, this is decreasing, because the communities right now, are mobilising.

Indeed, nine interviewees suggested that community outreach programs, parent-teacher associations (PTAs), opportunities for scholarships, and/or adult literacy programs are helping to mobilize parents and the community to take an 
interest in educational attainment, especially for girls. Once again, it is important to reiterate that these findings represent the perspectives of practitioners and, as many scholars have articulated, institutional policies and practices among refugee service providers do not necessarily translate to internalized cultural change among the refugees themselves. ${ }^{72}$ Thus, the mere act of NGOs targeting girls as "vulnerable" doesn't necessitate girls' increased safety or improved social status in relation to boys. ${ }^{73}$ That said, our participants felt strongly that educational programming, particularly for women and girls at all levels, can assist with long-term gender equity and protection goals, thus corroborating Quinn's position that:

"Adopting a holistic approach to education-including not only primary and secondary education but tertiary or higher education, vocational and technical educationincreases opportunities for and effectiveness of protection work." 74

In the recent 2010 UNESCO report, Protecting Education from Attack, Quinn emphasizes the interdependence of all levels of education, stating: "The belief in education is strengthened when young people and adults alike have hopes of advancing their interests through learning, for themselves or for family or community members." 75

\section{Teacher Training Programs (TTP)}

For Quinn, this independence is manifested throughout the education system, the most obvious example being the fact that primary and secondary schools require trained teachers, produced through higher education and training. ${ }^{76}$ Interviewees repeatedly noted this correlation, suggesting that a lack of trained teachers and low requirements for qualifications resulted in poor educational attainment among children and high turnover among staff (Interviewees 3, 7, $8,10,12,15)$. One NGO worker explained:

Every month we recruit. Why? Teaching is very challenging. Dealing with children is more challenging. Dealing with them when you are untrained is more challenging. So they find themselves to be in a very difficult situation [...] So teachers, they find, it is better to go to other jobs that don't require this professional work and technical difficulty [...] The mass movement of teachers from the education sector, to other sectors or NGOs, is very high.-Interviewee 7

Additionally, incentive workers in the camps are paid on a salary scale, whereby all refugee teachers are paid the same wage, regardless of training (Interviewee 10). In his research on education in Dadaab, Siraji, a student resettled by WUSC, found that one Kenyan primary school teacher in the camps is paid a salary comparable to ten salaries of incentive workers, and at the secondary level this rises to fifteen salaries. ${ }^{77} \mathrm{He}$ also found that this causes turnover in the camps, as the stressful conditions are not considered equal to the pay when teachers are not adequately prepared for their work (Interviewees 3, 7, 10). As a result, UNHCR implemented a new salary scale for incentive teachers, and NGOs have initiated the following TTP to improve education quality within the camps.

In 2009, an Italian NGO, the Association of Volunteers in International Service (AVSI), sponsored 126 refugee teachers to complete a one-year distance education teaching diploma offered in partnership with Mount Kenya University, which followed the Kenyan Teacher Training College Syllabus. In May 2010, UNHCR also coordinated with Masinde Mulito University in Kenya to run a fifteenweek in-training program for 100 refugee teachers, offering teaching accreditation through simultaneous part-time teaching and afternoon professional development training. The positive impact of TTP was noted by five participants ( 2 , $3,7,8,10)$ who believe that training has contributed to an increase in school standards and student attainment.

With the majority of teachers in the camps being untrained, teachers often experience harsh working conditions, which can result in low self-esteem-all of which contributes to high turnover (Interviewees 7, 10). UNHCR and NGOs are attempting to provide training and development opportunities to refugee incentive teachers, but this is difficult due to the aforementioned encampment policies in Kenya and the inability to utilize modern technology for online education training due to geographical restrictions and high cost (Interviewees 2, 3, 4, 9, 11, 12, 15). It could also be argued that some teachers experience a lack of motivation to improve the education system, as there is no direct correlation between training and improved economic situation. ${ }^{78}$ However, findings indicate that UNHCR's new salary scale for incentive teachers, based on training and experience, is having a positive impact on teacher performance and student attainment. According to Siraji,

Through the [teacher training] scholarship program, many untrained refugee teachers had the opportunity to upgrade and acquire teaching skills [...] The trained teachers came back to the camps [to be] absorbed in the education sector with a higher pay in lieu of the untrained teachers [...] The pay rise of the trained teachers acted as a driving force for many [teachers] to scramble to further their studies. ${ }^{79}$

TTP has been strengthened by innovative collaboration with local Kenyan universities, such as Masinde Mulito University, which runs in-service teacher-training programs whereby teachers receive training on-site while 
continuing to teach within the camps. Additionally, bringing experienced teachers into the camps allows for mentorship and professional development, at a lower cost than sending numerous refugee teachers outside, which would also create a gap in the teaching force. Interviewees 3 and 15 noted that a new collaboration with Kenya's Centre for Distance and Online Learning may also address the need to assist with supervision and support for teachers by offering further development training opportunities through CD-ROMs and limited Internet, also at a lower cost than onsite training. These findings demonstrate what Chambers describes as an effort to use "technologies to decrease rather than increase disparities," as "e-learning eliminates the barriers of time and distance, creating universal learning-ondemand opportunities for people." 80

\section{Higher Education}

These models of e-learning, distance education, and university partnership exemplify the benefits of exploring "alternative, flexible modes of delivery and accreditation systems." 81 Not only have such efforts been encouraging in a TTP context, but they have also generated more opportunities for higher education.

\section{Distance Learning}

Distance learning is rapidly expanding in the Global South, particularly in Sub-Saharan African, and as of the twentyfirst century, "the five largest programs in the world are all based in developing countries." 82 One of the benefits of distance learning and ICT models in contexts of displacement and exile is that they can enable the development of transferable skills which later assist refugees with re-integration into the state system. ${ }^{83}$ In Kakuma, Jesuit Refugee Service implements a distance learning program with the University of South Africa, whereby an institutional partnership allows for thirty students per year to receive scholarships to complete diplomas in community development or public health. Additionally, in June 2010, JRS formed further partnerships with American Jesuit universities to provide further distance learning opportunities for twenty refugee students (Interviewees 2 and 3). In 2011, JRS expanded this program to one hundred refugees, providing a three-year diploma, accredited by US-based Regis University in Denver, Colorado, in humanities, leadership, business studies, or communication. ${ }^{84}$ However, there are challenges: Interviewee 2 reported that Internet is costly and unreliable, meaning that few students can participate in the program at any given time, with numerous problems in obtaining the necessary materials to study effectively. We observed this challenge first-hand during visits to schools and local offices, where loading an Internet page took up to four minutes, something which would take less than two seconds in Nairobi, and only one computer could access the Internet at a time, resulting in long waiting times for students hoping to use technology for learning. JRS reports to have combatted these issues by "partnering with companies like Safaricom, Libco and Microsoft," offering the best possible Internet connections and computer programs, including a brand new computer lab, where over twenty computers each have access to the Internet. ${ }^{85}$ Interviewee 15 noted that three organizations have computer labs (JRS, WTK, and Don Bosco), but that refugees can only use them when registered for appropriate courses.

\section{Scholarships}

In addition to distance education programs, plus funding boarding school scholarships for girls, vulnerable children, and those with disabilities, JRS also sponsors students to attend Kenyan universities, with the belief that higher education will provide skills for repatriation and will inspire other refugees to achieve (Interviewee 3). WTK also works to establish Memorandums of Understanding with Kenyan universities, classifying refugees as domestic students for fee assessment purposes; at the time of our research, agreements were signed with four Kenyan universities. WTK and UNHCR also provide over one hundred in-country scholarships for students to attend these universities, while sponsoring over thirty per year to complete graduate studies at universities in the United Kingdom.

Other higher education scholarship programs include: the World University Service of Canada Student Refugee Program (SRP); the Albert Einstein German Academic Refugee Initiative Fund (DAFI); DDPuri; and the Dadaab Young Women Scholarship Initiative (DYWSI). The SRP sponsors approximately thirty-five students from Kenyan camps each year to Canada, who arrive as permanent residents and receive a university scholarship. ${ }^{86}$ DAFI, funded by Germany, operates around the world and provides local sponsorship for refugees to attend universities in Africa, focusing on girls and those with disabilities. DDPuri provides scholarships for teachers to attend Kenyan colleges and to return on holidays to assist with education in the camps. DYWSI is a new initiative whereby the US organization Matawi funds young women's scholarships in Kenyan universities.

Siraji, in his WUSC student report on the effects of scholarships on refugee attainment, noted the following findings regarding education in the camps:

While the number of DAFI students is small, their impact is huge because of their areas of expertise. Some work in business and government, others are employed by UNHCR and other United 
Nations Agencies (19) [...] [Additionally], the establishment of secondary school scholarship opportunities in the camps added to the hard work and subsequent good performance in primary schools. ${ }^{87}$

There is also a unique case of a student who achieved the highest-ever grades in Dadaab and placed eighth overall in Kenya, receiving a full scholarship to Princeton University. While this occurrence was extremely rare, Siraji notes: "The securing of scholarship by [the student] at Princeton acted as the defining moment in the lives of many, as it acted as an overwhelming impetus for many students to work hard." 88

While five participants reported the positive impact of scholarships on educational attainment, both in-country and international, Byamungu cites additional challenges with scholarship programs, such as how eligibility criteria favour youth under the age of twenty-five, providing few opportunities for adults or learners who have had a break in schooling, a common occurrence in the camps. ${ }^{89}$ There have also been years in which there was no funding available for DAFI and DDPuri scholarships, for example, diminishing student morale. Byamungu and Siraji, along with Interviewees 2 and 3, noted that scholarships are also aimed at single individuals, but most youth in the camps are often supporting families or extended families, causing resentment and hostility. ${ }^{90}$ There was also a noted debate surrounding "brain-drain," as three interviewees explained the lower cost of funding refugees to attend educational institutions locally rather than internationally, meaning that "more people could be helped who would return to their countries to make change, rather than staying abroad" (Interviewee 3). However, a former refugee student also noted:

On graduation and completion of their scholarships, students are mandated to return to the camps as the permit to stay in Nairobi expires on their graduation. Consequently, on returning to the camps, they will not secure paying jobs except as incentive employees with the agencies, as there are no work permits [allowed] for refugees. Their redundancy in the camps frustrates everybody that had confidence in them as the paper-made diplomas and degrees don't make much difference in their lives [...] The promises of the foreseeable future for the few lucky-come-lucky ones are barricaded by another Berlin wall that can only be destroyed through resettlement or the provision of work permits. ${ }^{91}$

\section{Community Secondary Schools}

The chance to go abroad for higher education does not necessarily signify a complete divergence from the camp education system. For example, in 2008, students sponsored through the SRP began an association called Students for Refugee Students (SRS) in order to raise additional funding for supplies and textbooks in for the Community Secondary Schools in Dadaab. Furthermore through transnational communications, many students in SRS endeavour to remain active community mentors for community school students and teachers.

The establishment of Community Secondary Schoolsone in each sub-camp-began as an idea put forth by community leaders in Dadaab in response to the limited absorption capacity of existing secondary schools in the camps (Interviewee 1). Through a Memorandum of Understanding between UNCHR, Care, and the community in 2008, the refugees accepted responsibility for paying for incentive teachers and school supplies, while Care provided support in the management and running of the schools, and UNHCR assisted in liaising with donors. ${ }^{92}$ However, as of 2010, Dadaab's secondary schools, including community schools, have been transferred from Care's mandate to that of WTK. While infrastructure and funding were partially supplied by international donors, including UNHCR goodwill ambassador Jesús Vázquez from Spain, who sponsored one school (Interviewee 7), the community has used transnational networks to obtain funding for supplies and books. They further decided to charge an annual school fee of 2,700 Kenyan shillings (\$30 USD), using the fees to pay incentive teachers.

As SRP scholarship winners are secondary graduates who must wait one year before resettling to Canada, many of these students volunteered to be teachers in the schools, with PTAs being an active component of school and student accountability. Together with the assistance of the donor community, parents and young adults in the refugee community were able to mobilize their efforts and double the provisioning of secondary school in the camps. This remarkable accomplishment illustrates how opportunities for higher learning can bolster parents' value for education and provide young adults with the chance to give back to their community, be it through teaching, activism, or remittances.

\section{Concluding Comments and Recommendations}

In this paper we have demonstrated how access to higher education, in contexts of protracted displacement, is beneficial to refugees not only once a durable solution has been found, but also during times of conflict and exile. Opportunities for higher learning can provide refugees with the skills needed to improve camp conditions, either as incentive workers, as teachers for NGOs, or through transnational efforts such as the Students for Refugee Students association. As Quinn points out, a community's “belief in education is strengthened when a fully functioning, holistic 
system of education is in place; when primary education holds some possibility of passage to secondary, vocational or technical levels, or even to university." 93 This also holds true in refugee camps, where higher education programs can help strengthen community learning, cultivate social development, promote ideas of gender equality, and reduce youth social deviancy by encouraging school attendance.

While educational opportunities that exist outside of the camps, such as the WUSC SRP, can provide beneficiaries with opportunities for durable solutions, and while these opportunities support refugee communities through remittance sending, they should not overshadow the importance of educational opportunities within the camps. Higher and adult education programming in Kakuma and Dadaab facilitates mentorship and professional development opportunities for refugee teachers and incentive workers, enhancing refugee self-sufficiency as well as the overall quality of education provision. Moreover, in-camp training and education are more cost-effective, reduce gaps in the workforce when teachers must leave, and are more in line with Kenya's current refugee encampment policy.

Our findings are particularly salient as commentary on the "relief versus development" framework. Currently, higher education cannot be prioritized in a donor-driven environment, structured to maintain a state of "permanent temporariness." 94 By failing to recognize the protracted nature of refugee situations in order to maintain this narrative of temporariness, donors restrict themselves from providing opportunities for learning and skills development beyond primary and secondary education.

The educational realities in refugee camps in Kenya suggest that international efforts should advocate for education as a central part of both emergency relief efforts and as a long-term development solutions. We agree with Kaiser that, although "developmental approaches promise a number of advantages in protracted refugee situations," they must be pursued within frameworks which ensure that protection, and legal and socio-economic needs, remain at the fore. ${ }^{95}$ To achieve the desired policy change, host states must come to understand the social benefits of education for both refugees and local communities as a rationale for implementation; this would also address the criticism that the development model is often label-based rather than needs-based, creating tensions between host communities who are "poor" and those who are "refugees."

During our time in Kenya, we witnessed the indomitable spirit of refugee communities who pursue education in times of conflict and instability. According to many of our informants, care and maintenance are not enough-service provision should be expanded to provide skill development opportunities (Interviewees 3, 7, 8). Protracted refugee situations call for long-term planning, and this must begin by interrogating the temporality of development assistance. Educated refugees often return to camps or work from abroad to raise educational attainment for others in their communities; ${ }^{97}$ moreover, educated refugees can provide invaluable expertise for development if repatriated or settled in a new country. As such, opportunities for adult and higher education "should be understood within a forwardthinking framework of development, rather than in terms of aid or assistance." 98 In sum, if provided with the necessary opportunities for higher learning, refugee communities can actively contribute to the type of creative, culturally specific solutions to twentieth-century challenges that the international community is seeking.

\section{Notes}

1. Nancy Birdshall, "Public Spending on Higher Education in Developing Countries: Too Much or Too Little," Economics of Education Review 15, no. 4 (1996); David Bloom, David Canning, and Kevin Chan, "Higher Education and Economic Development in Africa" (Washington, DC: World Bank, 2005); Wout Van Den Bor and James Shute, "Higher Education in the Third World: Status Symbol or Instrument for Development?" Higher Education 22 (1991); Task Force on Higher Education and Society, "Higher Education in Developing Countries: Peril and Promise" (Washington, DC: World Bank, 2000).

2. Basic education includes education at the primary and secondarylevel,bothformalandnon-formal;seeUNESCO2000, http://www.unesco.org/education/efa/wef_2000/regional _frameworks/frame_europe_north_america.shtml. Such priorities were manifested in a severe deterioration of higher education in Africa; while the World Bank's education-sector spending from 1985-89 was at 17 per cent, this dropped to 7 per cent between 1995 to 1999. See Bloom, Canning, and Chan, "Higher Education and Economic Development in Africa"; see also Joel Samoff and Bidemi Carrol, "Conditions, Coalitions, and Influence: The World Bank and Higher Education in Africa," in Annual Conference of Comparative and International Education Society (Palo Alto: Stanford University, 2004).

3. Bloom, Canning, and Chan, "Higher Education and Economic Development in Africa."

4. Task Force on Higher Education and Society, "Higher Education in Developing Countries: Peril and Promise" (Washington, DC: World Bank, 2000); Wout Van Den Bor and James Shute, "Higher Education in the Third World: Status Symbol or Instrument for Development?" Higher Education 22 (1991).

5. Van Den Bor and Shute, "Higher Education in the Third World." 
6. Task Force on Higher Education and Society, "Higher Education in Developing Countries: Peril and Promise" (Washington, DC: World Bank, 2000).

7. Ibid.; World Bank, Financing Higher Education in Africa (Washington, DC: World Bank, 2010).

8. Van Den Bor and Shute, "Higher Education in the Third World."

9. Joel Samoff and Bidemi Carrol, "Conditions, Coalitions and Influence: The World Bank and Higher Education in Africa" (paper presented at the Annual Conference of the Comparative and International Education Society, Salt Lake City, March 8-12, 2004).

10. Ibid., 15.

11. Bloom, Canning, and Chan, "Higher Education and Economic Development in Africa.

12. "Constructing Knowledge Societies: New Challenges for Tertiary Education” (Washington, DC: World Bank, 2002), xix.

13. UNESCO, Dynamic Data Mapping, Global Monitoring Report 2008, http://www.unesco.org/en/efareport/ddm/.

14. UNHCR, "Protracted Refugee Situations," Executive Committee of the High Commissioner's Programme, Standing Committee 30th meeting, EC/54/SC/CRP.14, 10 June 2004; US Committee for Refugees, "World Refugee Survey 2004" (Washington, DC: USCR, 2004).

15. Birdshall, "Public Spending on Higher Education in Developing Countries"; Task Force on Higher Education and Society, "Higher Education in Developing Countries: Peril and Promise" (Washington, DC: World Bank, 2000); Bloom, Canning, and Chan, "Higher Education and Economic Development in Africa; "Financing Higher Education in Africa," in Directions in Development: Human Development (World Bank, 2010); Van Den Bor and Shute, "Higher Education in the Third World."

16. Task Force on Higher Education and Society, "Higher Education in Developing Countries: Peril and Promise" (Washington, DC: World Bank, 2000).

17. Bloom, Canning, and Chan, "Higher Education and Economic Development in Africa.

18. NGO Network of Integration Focal Points, "Policy Briefing on Access to Vocational Training and (Higher) Education for Refugees and Migrants in Europe ", 1, http://www.epim .info/wp-content/uploads/2011/02/ECRE-Policy-Briefing _Vocational-training-higher-education.pdf.

19. Gil Loescher and James Milner, "A Framework for Responding to Protracted Refugee Situations," in Protracted Refugee Situations: Politics, Human Rights and Security Implications, ed. Gil Loescher et al. (Tokyo: UN University Press, 2008).

20. Barbara Zeus, "Exploring Paradoxes around Higher Education in Protracted Refugee Situations," in Borderless Education: The Provision of Tertiary Degree Programmes to Longterm Refugees (Toronto: Centre for Refugee Studies, York University, 2010), 6.
21. L. Davies, "Capacity Development for Education Systems in Fragile Contexts" (working paper, Centre for International Education and Research, University of Birmingham, in collaboration with the European Training Foundation (ETF) and Deutsche Gesellschaft für Technische Zusammenarbeit (GTZ), Sector Project Education and Conflict Transformation, 2009), 15; P. Buckland, "Reshaping the Future: Education and Postconflict Reconstruction" (Washington, DC: World Bank, 2005); K. Bush and D. Saltarelli, "The Two Faces of Education in Ethnic Conflict: Towards a Peacebuilding Education for Children" (Florence: UNICEF Innocenti Research Centre, 2000); L. Davies, Education and Conflict: Complexity and Chaos (London: Routledge, 2004); L. Davies, Educating against Extremism (Stoke-on-Trent: Trentham, 2008); OECD, "Service Delivery in Fragile Situations: Key Concepts, Findings and Lessons" (OECD-DAC discussion paper, OECD, Paris, 2008); P. Rose and M. Greeley, "Education in Fragile States: Capturing Lessons and Identifying Good Practice" (paper prepared for the DAC Fragile States Group, 2006); K. Seitz, "Education and Conflict: The Role of Education in the Creation, Prevention and Resolution of Societal Crises-Consequences for Development Cooperation" (Eschborn: Deutsche Gesellschaft für Internationale Zusammenarbeitft TZ, 2004).

22. Zeus, "Exploring Paradoxes around Higher Education in Protracted Refugee Situations," 4.

23. Jandranka Mimica and Paul Stubbs, "Between Relief and Development: Theories, Practice and Evaluation of Psychosocial Projects in Croatia," Community Development Journal 13 (1996): 283.

24. Ibid.

25. Kerry Demusz, "From Relief to Development: Negotiating the Continuum on the Thai-Burmese Border," Journal of Refugee Studies 2 (1998): 232.

26. Mimica and Stubbs, "Between Relief and Development."

27. Harrell-Bond, Imposing Aid: Emergency Assistance to Refugees (Oxford: Oxford University Press, 1986); Roger Zetter, "Labelling Refugees: Forming and Transforming a Bureacratic Identity, Journal of Refugee Studies 4 (1991): 39-61; Jennifer Hyndman, Managing Displacement: Refugees and the Politics of Humanitarianism (Minneapolis: University of Minnesota Press, 2000); Black, "Putting Refugees in Camps," Forced Migration Review 2 (1998): 4-7.

28. Mimica and Stubbs, "Between Relief and Development," 283.

29. Ibid

30. Demusz, "From Relief to Development," 232.

31. Mimica and Stubbs, "Between Relief and Development," 283.

32. Ibid.

33. Tania Kaiser, "Participating in Development? Refugee Protection, Politics and Developmental Approaches to Refugee Management in Uganda, Third World Quarterly 26, no. 2 (2005): 351-67.

(C) Laura-Ashley Wright and Robyn Plasterer, 2010. This open-access work is licensed under a Creative Commons AttributionNonCommercial 4.0 International License, which permits use, reproduction and distribution in any medium for non-commercial purposes, provided the original author(s) are credited and the original publication in Refuge: Canada's Journal on Refugees is cited. 
34. Jeff Crisp, "Mind the Gap! UNHCR, Humanitarian Assistance and the Development Process," International Migration Review 35, no. 1 (2001): 169.

35. Gil Loescher, Alexander Betts, and James Milner, The United Nations High Commissioner for Refugees: The Politics and Practice of Refugee Protection into the 21st Century (New York: Routledge, 2008); Monica Duffy Toft, "The Myth of the Borderless World: Refugees and Repatriation Policy," Conflict Management and Peace Science 24, no. 2 (2007): 139-57; B. S. Chimni, "From Resettlement to Involuntary Repatriation: Towards a Critical History of Durable Solutions to Refugee Problems," New Issues in Refugee Research working paper no. 2, 2008.

36. Jennifer Hyndman, "A Post-Cold War Geography of Forced Migration in Kenya and Somalia," Professional Geographer 51, no. 1 (1999): 109.

37. UNHCR, "UNHCR Annual Report Shows 42 Million People Uprooted Worldwide [Press Release]," \{UNHCR, $2009 \# 549\}$, accessed January 21, 2010, http://www.unhcr .org/4a2fd52412d.html.

38. Loescher and Milner, "A Framework for Responding to Protracted Refugee Situations," 124.

39. Cindy Horst, Transnational Nomads: How Somalis Cope with Refugee Life in the Dadaab Camps of Kenya, Studies in Forced Migration (New York and Oxford: Berghahn, 2006).

40. UNHCR, "UNHCR Sub-Office Dadaab Operations Briefing Kit" (unpublished document, UNHCR, Dadaab, 2009); UNHCR, "Dadaab Secondary Education Strategy, November 2009"(unpublished document, UNHCR, Dadaab, 2009); UNHCR, "Camp Population Statistics by Country of Origin, Sex and Age Group, 30 Jan 2011" (unpublished document, UNHCR, Dadaab, 2011).

41. UNHCR, "UNHCR Sub-Office Dadaab Operations Briefing Kit" (unpublished document, UNHCR, Dadaab, 2009).

42. UNHCR. Background on Somalia, accessed February 25, 2011, http://www.unhcr.org/cgi-bin/texis/vtx/ page? page $=49 \mathrm{e} 483 \mathrm{ad6}$; UNHCR. Kenya Fact Sheet as of March 31st 2011 (unpublished document).

43. UNHCR, "Camp Population Statistics by Country of Origin, Sex and Age Group, 30 Jan 2011" (unpublished document, UNHCR, Dadaab, 2011).

44. UNHCR, "UNHCR Sub-Office Dadaab Operations Briefing Kit" (unpublished document, UNHCR, Dadaab, 2009); UNHCR, "Dadaab Secondary Education Strategy, November 2009" (unpublished document, UNHCR, Dadaab, 2009).

45. UNHCR, "UNHCR Sub-Office Dadaab Operations Briefing Kit" (unpublished document, UNHCR, Dadaab, 2009).

46. Ibid.; Interviewee 1, 2009.

47. UNHCR. "Dadaab Secondary Education Strategy, November 2009" (unpublished document, UNHCR, Dadaab, 2009).

48. WTK (Windle Trust Kenya), "Monthly Education Statistics for Secondary Schools in Dadaab in 2010" (unpublished document, Windle Kenya Trust, Dadaab, Kenya, 2010).
49. Ibid.

50. WTK (Windle Trust Kenya), "Kakuma Refugee Camp Population Statistics" (unpublished document, Windle Trust Kenya, Kakuma, 2011).

51. Ibid.

52. WTK (Windle Trust Kenya), "Kakuma Refugee Camp Education Enrollment Statistics, 2009 and 2011" (unpublished document, Windle Trust Kenya, Kakuma, 2011).

53. Ibid.

54. The Girl Child Education Program is funded though the World University Service of Canada (WUSC) and implemented by Windle Trust Kenya, with the support of UNHCR.

55. O'Donoghue and Punch define triangulation as a "method of cross-checking data from multiple sources to search for regularities in the research data"; T. O'Donoghue and $\mathrm{K}$. Punch, Qualitative Educational Research in Action: Doing and Reflecting (Oxon: Routledge, 2003), 78.

56. C. Weston et al., "Analyzing Interview Data: The Development and Evolution of a Coding System," Qualitative Sociology 24, no. 3 (2001): 394.

57. Robert Schweitzer and Zachary Steel, "Researching Refugees: Methodological and Ethical Considerations," in Doing Cross-Cultural Research: Ethical and Methodological Perspectives., ed. Pranee Liamputtong (Netherlands: Springer, 2008), 15.

58. Catriona Mackenzie, Chris McDowell, and Eileen Pittaway, "Beyond 'Do No Harm': The Challenge of Constructing Ethical Relationships in Refugee Research," Journal of Refugee Studies 20, no. 2 (2007), 303, 314.

59. D. Mwangi, Towards Sustainable Education for Female Victims of Armed and Civil Conflict (Nairobi: Forum for African Women Educationalists, 1995), 10.

60. While beyond the scope of this paper, Robyn Plasterer is currently conducting interviews with former refugee teachers who have been resettled through the WUSC program, in order to elicit youth perspectives on education in Kakuma and Dadaab.

61. Karen Jacobsen and Loren B. Landau, Researching Refugees: Some Methodological and Ethical Considerations in Social Science and Forced Migration, New Issues in Refugee Research (Geneva: UNHCR, 2003), 195.

62. G. Bowman, "Nationalizing the Sacred: Shrines and Shifting Identities in the Israeli-Occupied Territories," in Man: The Journal of the Royal Anthropological Institute 29, no. 3: 431-60; Raymond Lee, Dangerous Fieldwork (Thousand Oaks: Sage, 1995), 23.

63. Karen Jacobsen and Loren B. Landau, Researching Refugees.

64. Participants who were willing to have their interviews recorded were asked to provide us with their email contact information if they wished to review the transcripts.

65. The term "incentive worker" refers to a refugee who works for a UN or NGO agency in exchange for monthly "incentive" payments, which are usually substantially lower than the monthly wages of non-refugee staff. 
66. Programs such as the Nike Together for Girls sponsorship program, which provided scholarships for TVET but was cancelled when funding ran out.

67. Kenya's current asylum policies do not authorize refugees to work; see J. Milner, Refugees, the State and the Politics of Asylum (Basingstoke: Palgrave Macmillan, 2009).

68. See also Gerard Byamungu, "Tertiary Education Opportunities in Kakuma Refugee Camp," in Unpublished Thesis for the World University Service of Canada Student Refugee Program (Dadaab: Windle Trust Kenya-Kakuma Office, 2009).

69. J. H. Williams, On School Quality and Attainment. In Learning for a Future: Refugee Education in Developing Countries (Geneva: UNHCR, 2001), 93.

70. UNICEF, "Defining Quality in Education: A Paper Presented by UNICEF at the Meeting of the International Working Group on Education," (Florence: UNICEF, 2000), 6.

71. See also UNICEF, "Defining Quality in Education: A Paper Presented by UNICEF at the Meeting of the International Working Group on Education," (Florence: UNICEF, 2000).

72. For instance, according to Turner, despite promotion of gender empowerment in refugee camps in Tanzania, local conceptualization of gender relations among refugees remains relatively unchanged. Similarly, in her work in the Sahrawi refugee camps, Fiddian-Qasmiyeh reveals a disconnect between practitioners and refugees stemming from differing gender norms; rather than attempting to identify the reasons why certain women are reluctant to allow their daughters to participate in NGO programs, practitioners simply develop their initiatives to target "ideal" beneficiaries whom they know will participate. Thus the same groups of women and girls continue to benefit while those with alternative or more traditional understandings of femininity are overlooked. See: Simon Turner, "Angry Young Men in Camps: Gender, Age and Class Relations among Burundian Refugees in Tanzania," Working Paper No. 9, New Issues in Refugee Research (1999); Elena FiddianQasmiy'h, "'Ideal' Refugee Women and Gender Equality Mainstreaming: 'Good Practice” for Whom?” Refugee Survey Quarterly (2010).

73. Wenona Giles, "Gendered Violence in War: Reflections on Transnationalist and Comparative Frameworks in Militarized Conflict Zones," in Engendering Forced Migration: Theory and Practice, ed. D. M. Indra (New York and London: Berghahn Books, 1999).

74. UNESCO, "Protecting Education from Attack: A State-ofthe-Art Review," (France: UNESCO, 2010), 100.

75. Ibid.

76. Ibid.

77. M. A. Siraji, "Research on the Impact of Scholarships in Dadaab Refugee Camps," in Unpublished Thesis for the World University Service of Canada Student Refugee Program (Dadaab: Windle Trust Kenya-Dadaab Office, 2010).

78. Martin E. P. Seligman, Helplessness: On Depression, Development, and Death (San Francisco: W. H. Freeman, 1975), 10.
79. M. A. Siraji, "Research on the Impact of Scholarships in Dadaab Refugee Camps," 26.

80. J. Chambers, "Why America Needs a National Broadband Plan," Bloomberg Business Week, accessed August 12, 2010, http://www.businessweek.com/technology/content/ mar2010/tc20100316_597997.html.

81. Zeus, "Exploring Paradoxes around Higher Education in Protracted Refugee Situations," 5.

82. Task Force on Higher Education and Society, "Higher Education in Developing Countries: Peril and Promise" (Washington, DC: World Bank, 2000), 31.

83. Barbara Zeus, "Exploring Paradoxes around Higher Education in Protracted Refugee Situations: The Case of Burmese Refugees in Thailand" (London: University of London, 2009).

84. Jesuit Refugee Services, "JRS launches distance learning for refugees in Kenya," press release, accessed July 30, 2011, http://www.jesuit.org.uk/latest/110407.htm.

85. Ibid.

86. In total the WUSC SRP sponsors approximately sixty students each year, from Kenya, Malawi, and other countries of asylum where it has strong NGO partners.

87. M. A. Siraji, "Research on the Impact of Scholarships in Dadaab Refugee Camps," in Unpublished Thesis for the World University Service of Canada Student Refugee Program (Dadaab: Windle Trust Kenya-Dadaab Office, 2010), 28.

88. Ibid., 16 .

89. Gerard Byamungu, "Tertiary Education Opportunities in Kakuma Refugee Camp," in Unpublished Thesis for the World University Service of Canada Student Refugee Program (Dadaab: Windle Trust Kenya-Kakuma Office, 2009).

90. Ibid.; M. A. Siraji, "Research on the Impact of Scholarships in Dadaab Refugee Camps," in Unpublished Thesis for the World University Service of Canada Student Refugee Program (Dadaab: Windle Trust Kenya-Dadaab Office, 2010), 28.

91. M. A. Siraji, "Research on the Impact of Scholarships in Dadaab Refugee Camps," in Unpublished Thesis for the World University Service of Canada Student Refugee Program (Dadaab: Windle Trust Kenya-Dadaab Office, 2010), 40.

92. UNHCR, "Dadaab Secondary Education Strategy, November 2009" (unpublished document, UNHCR, Dadaab, 2009).

93. UNESCO, "Protecting Education from Attack: A State-ofthe-Art Review," (France: UNESCO, 2010), 100

94. A. J. Bailey, R. A. Wright, A. Mountz, and I. M. Miyares, "(Re)producing Salvadoran Transnational Geographies," Annals of the Association of American Geographers 92, no. 1 (2002): 138; Crisp, 190.

95. Kaiser, 2005, p.351.

96. Ibid. 
97. Claas Morlang and Sheri Watson, "Tertiary Refugee Education Impact and Achievements: 15 Years of DAFI" (Geneva: UNHCR, Technical Support Section, Division of Operation Services, 2007).

98. "Workshop Report," in Borderless Education: The Provision of Tertiary Programs to Long-term Refugees (Toronto: Centre for Refugee Studies (CRS), York University, 201012.

Laura-Ashley Wright has worked within the field of education and instability for over five years, with experience at the University of British Columbia, UNESCO, and the Government of Canada. She holds an MSc in comparative and international education from the University of Oxford, and is currently a consultant for the Inter-Agency Network for Education in Emergencies (INEE).

Robyn Plasterer has worked with various refugee education and resettlement programs in Canada for over five years. She holds an MSc in refugee and forced migration studies from the University of Oxford and is currently involved with refugee education projects at UNHCR Headquarters in Geneva.

\section{Acknowledgements}

We would like to thank all the refugee-service providers in Kenya who shared their knowledge, insights, and perseverance with us. In particular we must extend our immense gratitude to Marangu Njogu, Wenona Giles, Jennifer Hyndman, and everyone at Windle Trust Kenya, the Globalization of Protracted Refugee Situations Project, and WUSC for their inspiration and support. Additionally, this research would not have been possible without the generous funding of SSHRC, as part of the "Globalization of Homelessness in Protracted Refugee Situations" led by Giles and Hyndman. We must also thank Siraji and Byamungu for providing us with their own primary research and feedback for this paper. Finally, to all those who were, are, or will be refugees-we are not defined by labels but by our courage and morale. You have taught us so much and we endeavour to continue to learn. 